\title{
A novel role for the obesity-associated gene FTO in ciliogenesis and Wnt signalling
}

\author{
DPS Osborn ${ }^{\text {* }}$, S Mukherjee ${ }^{1}$, RM Roccasecca², I Barosso², D Stemple², PL Beales ${ }^{1}$, S Christou-Savina ${ }^{1}$ \\ From First International Cilia in Development and Disease Scientific Conference (2012) \\ London, UK. 16-18 May 2012
}

Common intronic variants in hFTO, an oxoglutaratedependent dioxygenase, were identified in GWAS to cause a predisposition to obesity. Inactivation of Fto in human and mouse models results in reduced viability, postnatal growth retardation, enhanced metabolism and loss of adipose tissue. However, the function of Fto during development and obesity remains unclear. We sought to clarify the function of Fto using zebrafish and cell culture. In zebrafish, we found loss of fto results in a ciliopathy-like phenotype. Morphants display small eyes, curved tails, otolith defects, disorganised melanocytes, situs inversus and renal cysts. Concurrently, cilia were absent in the olfactory bulbs and disorganised in the pronephric ducts (PND) and neural tube. Functional analysis of motile cilia in the PND and Kupffer's vesicle confirmed a direct ciliary defect. Wnt signalling has been implicated in adipogenesis and therefore we decided to investigate whether Fto may interact at this level. We found that $\beta$-Catenin and downstream target genes are consistently downregulated in fto morphants, HEK293T cells transfected with an shRNA Fto expressing plasmid, and Fto-/- MEFs. Furthermore, $\beta$ Catenin failed to translocate to the nucleus in Fto-/- MEFs in response to Wnt3a stimulation. By completing a comparative Wnt signalling phospho-antibody array, on Fto $+/+$ and Fto-/- MEFs, we identified increased PKC and CamKII activity: two non-canonical/Ca2+ Wnt components. Indeed, phospo-CamkII is up regulated in fto morphants and in response to Wnt3a in Fto-/- MEFs. Taken together, these data show that Fto acts as a key cilia-mediated regulator of canonical and non-canonical/ Ca2+ Wnt signalling.

Author details

${ }^{1}$ UCL Institute of Child Health, UK. ${ }^{2}$ Wellcome Trust Sanger Institute, UK.

* Correspondence: dan.osborn@ucl.ac.uk

${ }^{1}$ UCL Institute of Child Health, UK

Full list of author information is available at the end of the article
Published: 16 November 2012

doi:10.1186/2046-2530-1-S1-P75

Cite this article as: Osborn et al:: A novel role for the obesity-associated gene FTO in ciliogenesis and Wnt signalling. Cilia 2012 1(Suppl 1):P75.
Submit your next manuscript to BioMed Central and take full advantage of:

- Convenient online submission

- Thorough peer review

- No space constraints or color figure charges

- Immediate publication on acceptance

- Inclusion in PubMed, CAS, Scopus and Google Scholar

- Research which is freely available for redistribution

Submit your manuscript at www.biomedcentral.com/submit
C Biomed Central
C Biomed Central

(c) 2012 Osborn et al; licensee BioMed Central Ltd. This is an Open Access article distributed under the terms of the Creative Commons Attribution License (http://creativecommons.org/licenses/by/2.0), which permits unrestricted use, distribution, and reproduction in any medium, provided the original work is properly cited. 